\title{
Event Tradisi Sebagai Daya Tarik Kunjungan Wisatawan : Studi Kasus, Pasar Kampong Koepat Di Kabupaten Banyuwangi
}

Tradition Events as an Attraction for Tourists: Case Study, Pasar Kampong Koepat in Banyuwangi

\section{Safrieta Jatu Permatasari Andhika Wahyudiono \\ Dimas Imaniar}

Fakultas Ilmu Sosial dan Ilmu Politik, Universitas 17 Agustus 1945

Banyuwangi, Banyuwangi - Jawa Timur, 68416, Indonesia safrieta@untag-banyuwangi.ac.id, wahyudion21@gmail.com, dimasimaniars@gmail.com

Dikirim: 30Juni 2021, Direvisi: 30 Juni 2021, Diterima: 30 Juni 2021, Terbit: 30 Juni 202.

Sitasi: Permatasari, Wahyudiono, Imaniar, (2021), Event Tradisi Sebagai Daya Tarik Kunjungan Wisatawan : Studi Kasus, Pasar Kampong Koepat Di Kabupaten Banyuwangi, PRoMEDIA. Volume 7 (1), Juni 2021, hal 157- hal 156.

\begin{abstract}
Effective promotional activities are very essential in the development of tourism in an area. Promotional mix is one of the marketing tools, it can be used to inform, persuade and remind potential tourists. Apart from its natural beauty, Banyuwangi is also famous for its traditional culture which can attract many tourists to come. Together with tourism development, traditional culture is carried out as a tourist place. This study analyzes the development of the Koepat village market in Boyolangu Village, Giri District, Banyuwangi Regency, as an atourist attraction. This tradition has been praised by many people since it was held in 2018 , the community adopted it as "Kumpul tekO Punjer paPAT" (KOEPAT) with two goals, namely to support Banyuwangi Regency as a "tourism city" and to carry out the tradition in a more professional festival. so that not only to maintain the pride of the younger generation of the local community to preserve their traditions, but also as a unique tourist attraction in urban areas.
\end{abstract}


The method used is descriptive qualitative, data collection techniques are by observation and interviews with the head of the lurah, the social service office, the sub-district head and the staff of the Banyuwangi Regency Dispar, and literature studies. The author's interest in raising this case is because first, there is no community empowerment to increase public awareness in increasing economic independence through a local cultural tradition. Second, seeing that Banyuwangi is currently getting the title as the best festival city in Indonesia, this can be an alternative for Banyuwangi Regency in empowering the community through local cultural traditions in each region to increase tourist visits.

Keywords: Event Tradition, Tourism, Pasar Kampong Koepat

\begin{abstract}
Abstraksi
Kegiatan promosi yang efektif merupakan hal yang sangat esensial dalam pengembangan pariwisata di suatu daerah. Bauran promosi merupakan salah satu alat pemasaran, dapat digunakan untuk menginformasikan, membujuk dan mengingatkan calon wisatawan. Terlepas dari keindahan alamnya, Banyuwangi juga terkenal dengan tradisional budayanya yang dapat menarik banyak wisatawan untuk datang. Bersama dengan pengembangan pariwisata, budaya tradisional dilakukan sebagai tempat wisata. Penelitian ini menganalisis perkembangan pasar kampong koepat di Kelurahan Boyolangu Kecamatan Giri Kabupaten Banyuwangi, sebagai daya tarik atourist. Tradisi ini telah dipuji banyak orang mulai sejak digelar pada tahun 2018 lalu, masyarakat mengadopsinya sebagai "Kumpul tekO Punjer paPAT "(KOEPAT) dengan dua tujuan, yaitu adalah untuk mendukung Kabupaten Banyuwangi sebagai "kota pariwisata" dan untuk melakukan tradisi dalam festival yang lebih profesional sehingga tidak hanya untuk mempertahankan kebanggaan generasi muda dari komunitas lokal untuk melestarikan tradisi mereka, tetapi juga sebagai daya tarik wisata yang unik di perkotaan. Metode yang digunakan adalah deskriptif kualitatif, teknik pengumpulan data yaitu dengan observasi dan wawancara dengan kepala lurah, kantor dinas sosial, camat giri dan Staf Dispar Kabupaten Banyuwangi, serta studi literatur. Adapun ketertarikan penulis mengangkat kasus ini dikarenakan Pertama, belum adanya suatu pemberdayaan masyarakat untuk meningkatkan kesadaran masyarakat
\end{abstract}


dalam meningkatkan kemandirian ekonomi melalui suatu tradisi budaya lokal. Kedua, melihat dewasa ini Banyuwangi mendapatkan predikat sebagai kota festival terbaik di Indonesia, hal ini bisa menjadi alternatif Kabupaten Banyuwangi dalam melakukan pemberdayaan masyarakat melalui tradisi budaya lokal di setiap wilayahnya untuk meningkatkan kunjungan wisatawan.

Kata Kunci: Event Tradisi, Pariwisata, dan Pasar Kampong KOEPAT

\section{PENDAHULUAN}

Kabupaten Banyuwangi pernah dinobatkan sebagai Kota festival terbaik di Indonesia. Pada tahun 2019 dalam kalender event, yakni Majestic Banyuwangi Festival 2019 akan menampilkan 99 event dan top 3 event Banyuwangi yang masuk kedalam 100 events Wonderful Indonesia. Acara atau event ini sebagai cara untuk mendongkrak jumlah kunjungan wisatawan dan mengukuhkan Banyuwangi sebagai kota festival terbaik di Indonesia.

Penetapan Kabupaten Banyuwangi sebagai kota festival terbaik karena dinilai dari segi pertumbuhan event yang sangat pesat dan mengusung segenap potensi masyarakat, sehingga harapnnya juga mampu menumbuhkan kesejateraan masyarakat Banyuwangi. Disamping itu, Banyuwangi melakukan terobosan atau inovasi event pariwisata, sehingga setiap tahunnya jumlahnya semakin meningkat. Pada awal diselenggarakannya event tahun 2012, Banyuwangi baru memiliki duabelas event, tahun 2018 meningkat menjadi 75 (tujuh puluh lima) event, dan 
di tahun 2019 menjadi 99 (sembilan puluh sembilan) event. Oleh sebab itu penetapan banyuwangi sebagai kota festival terbaik karena pertumbuhan event yang sangat pesat dan menyertakan segenap potensi masyarakat sehingga mampu meningkatkan kesejahteraan masyarakat Banyuwangi karena seluruh event melibatkan potensi masyarakat.

Event pariwisata dapat menciptakan citra yang menguntungkan bagi suatu destinasi, memperluas musim wisata tradisional, mengembangkan permintaan wisatawan lebih merata melalui suatu daerah dan untuk menarik pengunjung asing dan domestik. Dalam hal ini event pariwisata dapat menciptakan persepsi pada wisatawan sehingga dapat mempengaruhi keputusan berkunjung dan menciptakan rasa suka atau senang sehingga mendorong wisatawan untuk menjelajahi lebih lanjut mengenai pariwisata di Kabupaten Banyuwangi. (Damster and Tassiopoulos, 2005:4)

Kampoeng Kopat ialah kepanjangan dari‘ Kumpul Teko Punjer Papat'. Terjadinya pasar ini agak unik. Berawal dari kegelisahan Generasi Pesona Indonesia (GenPI) Banyuwangi pasca event Banyuwangi Ethno Carnival (BEC). Karena, BEC mengambil tema Puter Kayun yang selaku kekayaan serta kearifan lokal warga Boyolangu. BEC waktu itu mengangkut Puter Kayun. Sesudah BEC berakhir instan tidak terdapat lagi aktivitas. Pasar ini dibesarkan secara swadaya warga Boyolangu. Karena, harapannya destinasi ini jadi motor ekonomi terbaik 
warga. Pasar Kampoeng Kopat pula ditunjukan bagaikan media berekspresi generasi milenial di Boyolangu.

Senada dengan temanya, pasar ini hendak menyajikan kuliner dengan bahan utama ketupat serta sejenisnya. Contohnya, Rujak Cingur serta Rujak Soto dengan bahan utama ketupat. Secara perinsip, kuliner yang hendak disajikan sangat banyak. Jadi tidak butuh menunggu Lebaran buat dapat menikmati ketupat. Tiap akhir minggu dapat menikmati ketupat khas Pasar Kampoeng Kopat.

Berdasarkan paparan di atas, maka sangat menarik untuk mengkaji sejauh mana event budaya tradisi pasar kampong Koepat sebagai modal sosial dalam perubahan sosial dan pemberdayaan masyarakat. Penelitian ini difokuskan pada dampak positif event budaya tradisi pasar kampong Koepat dalam memberdayakan masyarakat di Kelulahan Boyolangu Kecamatan Giri kabupaten Banyuwangi. Adapun ketertarikan penulis mengangkat kasus ini dikarenakan Pertama, belum adanya suatu pemberdayaan masyarakat untuk meningkatkan kesadaran masyarakat dalam meningkatkan kemandirian ekonomi melalui suatu tradisi budaya lokal. Kedua, melihat dewasa ini Banyuwangi mendapatkan predikat sebagai kota festival terbaik di Indonesia, hal ini bisa menjadi alternatif Kabupaten Banyuwangi dalam melakukan pemberdayaan masyarakat melalui tradisi budaya lokal di setiap wilayahnya..

\section{METODOLOGI PENELITIAN}




\section{A. Jenis Penelitian}

Metode penelitian yang digunakan adalah deskriptif kualitatif. Karena penelitian ini bermaksud untuk mengetahui dan memperoleh gambaran (uraian) yang lengkap tentang Peristiwa Tradisi sebagai Objek Kunjungan Wisatawan: Studi Kasus, Pasar Kampung Koepat di Kabupaten Banyuwangi.

\section{B. Pengumpulan Data}

Dalam menentukan informan pada penelitian ini dilakukan dengan dua tahap. Awalnya infroman ditetapkan dengan sengaja (purposive). Dalam tahapan ini ditentukan informan yang mengerti dan paham terkait dengan penelitian. Oleh karena itu, dalam hal ini ditentukan informan, 3 (tiga) orang dari pihak Pemerintah Kabupaten Banyuwangi, yaitu dari : (1) Kantor Dinas Sosial Banyuwangi, (2) Kantor Dinas Pariwisata Kabupaten Banyuwangi, (3) Kantor Kelurahan Boyolangu, dan (4) Kantor Kecamatan Giri.

Tahapan selanjutnya setelah informan ditetapkan dengan sengaja (purposive), maka penentuan informan berikutnya dilanjutkan secara mengalir dan mengembang (snowball sampling) pada informan yang lain hingga mencapai kejenuhan data. Pada tahapan ini ditetapkan juga beberapa standard, antara lain : usia antara 25 hingga 50 tahun, dapat memberi informasi data yang mewakili, tidak tuna wicara, memiliki pendidikan paling rendah setingkat $\mathrm{SD}$, mampu diajak berkomunikasi dengan baik, sanggup menjadi informan, dan jujur, serta tidak dikucilkan oleh warga setempat. 
Metode pengumpulan data yang dipakai yaitu melalui angket, wawancara, observasi, dokumentasi, dan lain-lain (Yusuf, 2014: 97). Selain itu Metode analisis data yang dipakai pada penelitian ini ialah metode analisis interaktif.

\section{PEMBAHASAN}

\section{A. Potensi Masyarakat Kelurahan Boyolangu}

Masyarakat Boyolangu memiliki banyak potensi. Potensi tersebut merupakan warisan dari generasi ke generasi yang telah dilestarikan oleh masyarakat boyolangu. Potensi tersebut antara lain :

1. Potensi Kuliner Masyarakat Boyolangu antara lain :

Sajian kuliner dengan bahan utama ketupat khas Boyolangu seperti rujak soto, rujak cingur, ketupat kare, ketupat opor, ketupat pecel pithik, ketupat ndok cit, jajanan tradisional, minuman tradisional, dan lain-lain. Potensi inilah yang dimanfaatkan oleh masyarakat Boyolangu untuk mendukung Kampung Kegiatan Pasar Jajanan Kopat di Desa Boyolangu.

2. Potensi Adat Masyarakat Boyolangu, memiliki berbagai macam adat-istiadat yang diatur dari generasi ke generasi. Antara lain : Tradisi puter kayun, Barong ider bumi, Kupat sewu, Ziarah atau nyekar makam Buyut Jakso.

3. Potensi Wisata di Boyolangu 
Festival puter kayun dan kupat sewu yang dilaksanakan pada bulan Syawal yang dihadiri oleh banyak turis lokal maupun mancanegara.

4. Potensi Kebijakan Program "Kanggo Riko"dari Pemerintah Kabupaten Banyuwangi memiliki Program Kebijakan Desa Cerdas yang berlaku di seluruh wilayah Banyuwangi.

5. Potensi program pemberdayaan perempuan dalam bentuk penyaluran kredit dan modal usaha bantuan bagi perempuan untuk usaha mikro. Oleh komunitas perempuan Boyolangu, dana bantuan digunakan sebagai modal usaha.

6. Potensi Koperasi Wanita Desa Boyolangu

Koperasi ini, baik manajemen dan anggotanya adalah wanita. Koperasi perempuan dimanfaatkan oleh masyarakat untuk mengajukan pinjaman dan memberikan bantuan modal usaha untuk membuat makanan yang dijual di pasar. Tidak hanya berupa produk makanan saja, namun juga bisa berupa souvenir (tas, dompet, kerajinan tangan) oleh komunitas Ibu-Ibu Paud kreatif di Boyolangu.

\section{B. Konsep Pasar Wisata Kuliner di Pasar Kampoeng Koepat, Kelurahan Boyolangu}

Mekanisme proses dan metode yang digunakan masyarakat dalam berintegrasi dari kegiatan ini dilaksanakan oleh Ketua RT, wakil Ketua RT, Ketua RW Boyolangu, tokoh 
desa, kelurahan boyolangu dan partisipasi masyarakat untuk menggali potensi menghadirkan destinasi wisata baru yaitu, Kampoeng Kopat. Musyawarah untuk berinovasi dilakukan di pertengahan 2018. Usai acara Banyuwangi Ethno Carnival (BEC) tempat Boyolangu yang mempersembahkan Festival Puter Kayun yang merupakan kearifan lokal dan kekayaan desa setempat. Setelah kegiatan BEC selesai, praktis tidak ada kegiatan lagi. Kemudian setelah diputuskan, hasil musyawarah baru disosialisasikan perihal rencana pasar Kampoeng Kopat kepada masyarakat. Hasilnya disambut antusias dan respon positif oleh masyarakat.

Pasar wisata kuliner terus dikembangkan Kabupaten Banyuwangi. Ditengah kelesuan ekonomi, tentu diperlukan inovasi untuk mendorong berbagai potensi yang dimiliki. Pasar kuliner merupakan terobosan untuk meningkatkan kesejahteraan warga di tiap-tiap desa. Pasar kampoeng kopat ini dikembangkan secara mandiri atau swadaya oleh masyarakat boyolangu dengan memanfaatkan koperasi wanita pemberi modal usaha bantuan untuk dijadikan modal berjualan makanan, jajanan tradisional dan sekaligus produk oleh-oleh kerajinan tangan, dan lain-lain. Harapannya destinasi ini bisa menjadi pendorong ekonomi terbaik masyarakat, komunitas, dan generasi milenial sebagai wadah berekspresi masyarakat, agar senantiasa memiliki kreativitas, produktivitas, serta inovasi yang tinggi. 
Selain itu, keberadaan simbol dan nilai yang dimiliki masyarakat sejak awal telah ada dan melekat pada hati masyarakat, Sehingga kesadaran untuk berpartisipasi dan mendukung Program Pasar Jajanan Kaki Lima otomatis ada dan tumbuh di masyarakat kelurahan Boyolangu, Kecamatan Giri, Kabupaten Banyuwangi.

Gambar 1. Pasar Kampong Koepat (Sajian kuliner berbahan dasar Kopat)

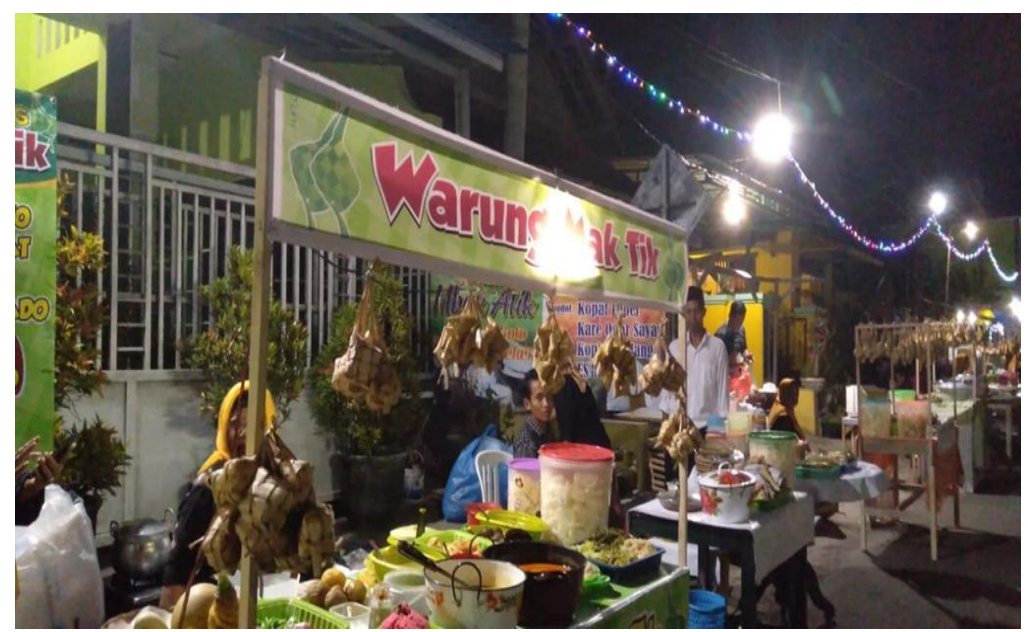

\section{Upaya Aparatur Pemerintah Kelurahan Boyolangu dalam mengembangkan Tradisi menjadi daya tarik wisata Desa}

Dalam melestarikan suatu tradisi atau adat istiadat di Kelurahan Boyolangu, dukungan aparatur pemerintah sangat penting yang tentunya diiringi dengan melihat aspek sosial untuk kepentingan masyarakat, seperti:

1. Melestarikan budaya atau tradisi desa 
2. Kolaborasi antara masyarakat dan kelurahan dalam melestarikan budaya

3. Meningkatkan partisipasi masyarakat, kreativitas dan inovasi generasi milenial dalam melestarikan budaya

4. Meningkatkan perekonomian dan kesejahteraan masyarakat.

\section{Pemberdayaan Masyarakat Desa}

Secara konseptual, empowerment ataupun pemberdayaan, berasal dari kata power (kekuasaan ataupun budaya). Dalam tiap program pemberdayaan warga mempunyai peranan serta tujuan yang berbeda sebab dalam bidang ekonomi, pemberdayaan ini menekankan pada pergantian kelompok sosial semacam pergantian perekonomian kelompok warga (pra sejahtera) menjadi lebih baik. Program pemberdayaan di bidang ekonomi" meliputi program proteksi lahan, intensifikasi pertanian, perkreditan, peternakan, koperasi industri, serta lain sebagainya. Program tersebut berbentuk pemberantasan literasi, pembelajaran kewirausahaan, kader, pelayanan kesehatan, perbaikan perumahan, penampungan para penganggur serta sebagainya"( Rasyad serta Suparna, 2003: 23).

Pemberdayaan menunjuk pada kemampuan orang, khususnya kelompok rentan dan lemah sehingga mereka memiliki kekuatan dan kemampuan dalam : 
a. Pemenuhan kebutuhan pokok sehingga mereka memiliki kebebasan (freedom), dalam artian bukan saja kebebasan menyampaikan opini, namun juga terbebas dari kelaparan, dan mampu memenuhi kebutuhan hidupnya

b. Meningkatkan akses produktif yang memungkinkan warga meningkatkan pendapatan, dan mendapatkan produk dan jasa yang dibutuhkan.

c. Berperan dalam proses pengembangan dan kebijakan yang berpengaruh pada masyarakat.

Peneliti berkesempatan mewawancarai Kepala Lurah Boyolangu, Bagaimana cara melakukan pembinaan masyarakat dalam melestarikan budaya desa di Kelurahan, beliau menjawab

“...Upayanya adalah dari aparatur kelurahan tentu mengikuti tugas dan fungsi dengan melakukan pembinaan kepada masyarakat, melibatkan masyarakat, tokoh adat, pemuda generasi milenial, semua kita sinergikan agar event ini nantinya bisa mendapat respon positif dan mendapat antusiasme dari masyarakat setempat.."(Helmi Afandi, S.AP pada tanggal 13 April 2020).

Pemaparan diatas menunjukkan bahwa peran Kelurahan sebagai aparatur pemerintah yaitu dengan mengerahkan pemuda setempat, serta masyarakat untuk bekerjasama dan ikut berpartisipasi melestarikan kearifan lokal atau budaya desa, didukung GenPI (Generasi Pesona Indonesia). Beliau beranggapan bahwa dengan kerjasama dan sinergi dari semua 
pihak tentunya bisa mensukseskan program Pasar Kampong Koepat ini.

Sedangkan peneliti menanyakan bagaimana proses pembentukan Pasar Kampong Koepat tersebut hingga bisa terselenggara sampai saat ini? Beliau menjawab :

“...asal mulanya ya diambil dari tradisi Puter Kayun dan juga kupat sewu (lebaran 10 hari) yang dilaksanakan setiap bulan syawal, akhirnya kami berpikir, kenapa kok tidak dijual saja. Akhirnya terbentuklah Pasar Kampong Koepat tersebut yang diselenggarakan setiap sabtu malam minggu. Karena kita nggak punya tempat wisata akhirnya kita mengusung konsep wisata kuliner..."(Helmi Afandi, S.AP pada tanggal 13 April 2020).

Sedangkan ketua RT Krajan Satu, Boyolangu menjelaskan : “...Karena pada waktu itu banyak kuliner wisata di setiap desa, diawali oleh desa kemiren, kemudian kami berfikir, kenapa kita tidak membuat sendiri. Kalau disini yang terkenal makanan kupat, tapi yang dijual sebetulnya juga tidak hanya makanan berbahan kupat saja. Ada jajanan khas daerah juga seperti lanun, cenil, pukis supaya lebih banyak macamnya. Ada kurang lebih sekitar 25 sampai 30 pedagang yang tergabung ..." (Ikhsan pada tanggal 15 April 2020).

Dari kutipan interview diatas menunjukkan bahwa pembinaan yang dijalankan oleh aparatur Kelurahan boyolangu 
bertujuan untuk meningkatkan perekonomian dan mensejahterakan masyarakat, saling bekerjasama dalam membangun desa dan otomatis penghasilan warga dapat meningkat sedikit demi sedikit.

Sedangkan dari segi pembiayaan untuk modal awal Pasar Kampong Koepat ini disamping swadaya masyarakat juga mendapat bantuan dari Kementerian Perdagangan yaitu bantuan gerobak untuk berjualan. Seperti hasil wawancara peneliti berikut ini :

“...awalnya itu dananya urunan masyarakat ada yang 100 rb, 200 rb kan ada biaya buat bikin Gapura, lampu-lampu itu kan perlu modal. Kemudian setelah Itu dapat bantuan dari Kementerian Perdagangan waktu itu dikasih untuk gerobak, sound system, dan tenda untuk berjualan..." (Helmi Afandi, S.AP pada tanggal 13 April 2020).

Dalam segi pembiayaan seperti hasil wawancara diatas dilakukan secara swadaya oleh masyarakat kelurahan boyolangu dan bantuan dari Kementerian Perdagangan dan kementerian koperasi. Pemerintah banyuwangi beserta Dinas terkait seperti Dinas Pariwisata memberi bantuan untuk promosi event Pasar Kampong Koepat seperti Baliho, promosi di media televisi dan online supaya diketahui masyarakat luas.

Gambar 2. Bantuan Gerobak untuk berjualan dari Kementerian Perdagangan 


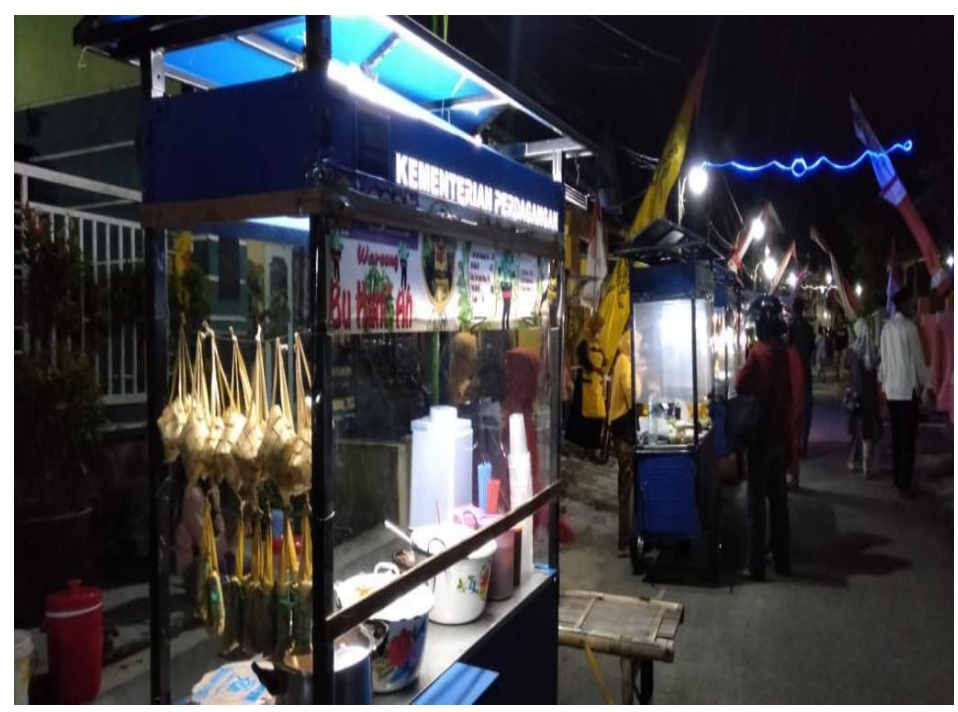

\section{E. Kerjasama Desa dalam Menyelenggarakan Event}

Dalam melanggengkan culture desa supaya dikenal daerah lain hingga wisatawan mancanegara, pemerintah kelurahan boyolangu harus mampu berkreasi dan membangun jejaring untuk bersinergi dan mendukung pelestarian budaya yang dimiliki desa agar dikenal luas oleh masyarakat luar.

Kepala Lurah Boyolangu mengatakan bahwa:

“...kita kan dibuatkan aplikasi yang bisa diunduh di android oleh Dinas pariwisata yaitu Nja-jan jadi kuliner sekabupaten ada disitu. Disamping itu bantuan dari Dinas Pariwisata berupa Baliho-baliho dipinggir jalan itu, kemudian kerjasama dengan trevel biro untuk mendatangkan wisatawan seperti waktu itu ada dari Amerika, Kroasia datang di acara 
Pasar Kampong Koepat, kerjasama dengan Miss Tourism and Culture "Olivia Gunawan" itu kan orang banyuwangi dibantu untuk promosi. Jadi intinya semuanya untuk pemberdayaan masyarakat..." (Helmi Afandi, S.AP pada tanggal 13 April 2020).

Gambar 3 Aplikasi Banyuwangitourism App milik Pemkab Banyuwangi

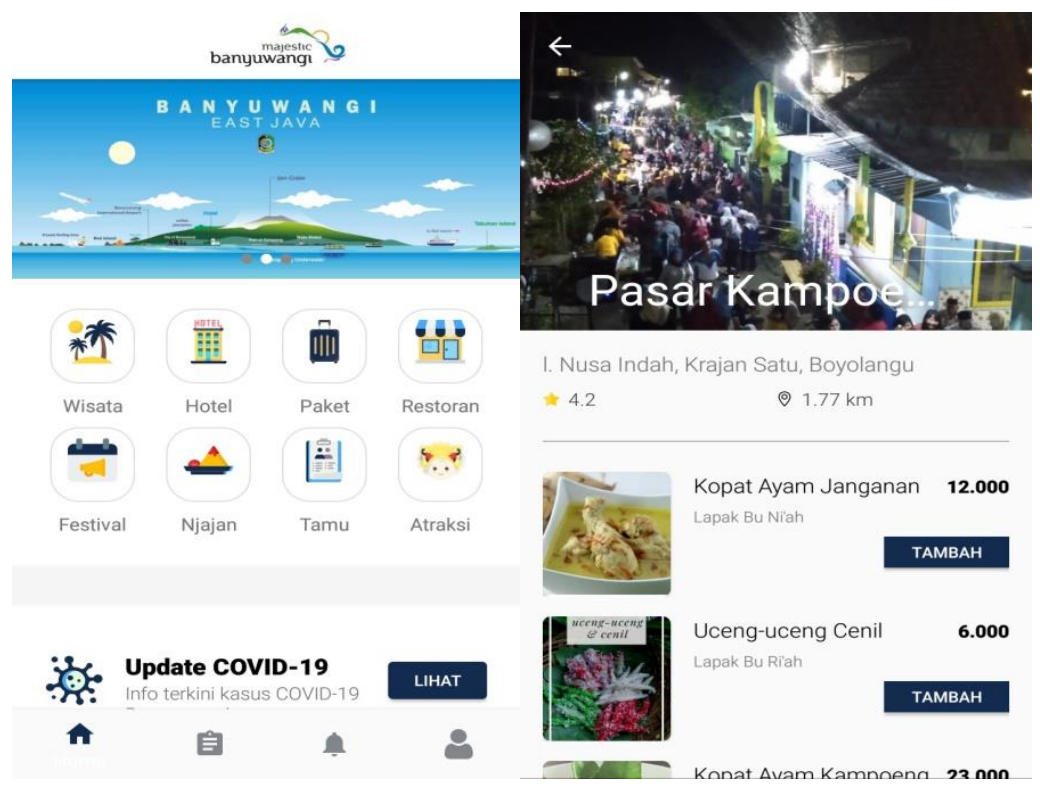

Dalam petikan wawancara terlihat bahwa Dinas Pariwisata turut menyumbang kontribusi yang besar dalam memberikan dukungan promosi acara pasar kampong Koepat agar lebih dikenal oleh masyarakat baik wisatawan lokal maupun mancanegara. Seperti dalam wawancara dengan staff dinas pariwisata berikut ini : 
“..untuk promosi memang kita lakukan secara intensif selain melalui baliho kita juga promokan melalui media sosial agar masyarakat mengetahui hari dan jamnya. apabila ada kunjungan wisatawan domestik atau mancanegara kami arahkan kesana..” (Riska pada tanggal 20 April 2020).

Dari kutipan wawancara diatas bisa dilihat bagaimana peran Pemerintah Kelurahan Boyolangu dalam mendukung pelstarian budaya desa. Pemerintah kelurahan tidak segansegan memohon bantuan pada Dinas Pariwisata dari segi promosi event desa agar dikunjungi masyarakat hingga wisatawan mancanegara. Hal itu memang terbukti, peneliti melihat seperti halnya disudut jalan kota dekat diselenggarakannya event terdapat Baliho besar yang memperlihatkan hari dan jam diadakannya Pasar Kampong Koepat yang desainnya sangat menarik untuk membuat masyarakat datang melihat dan membeli di wisata kuliner.

Gambar 4 Baliho event Pasar Kampong Koepat di

Lokasi strategis

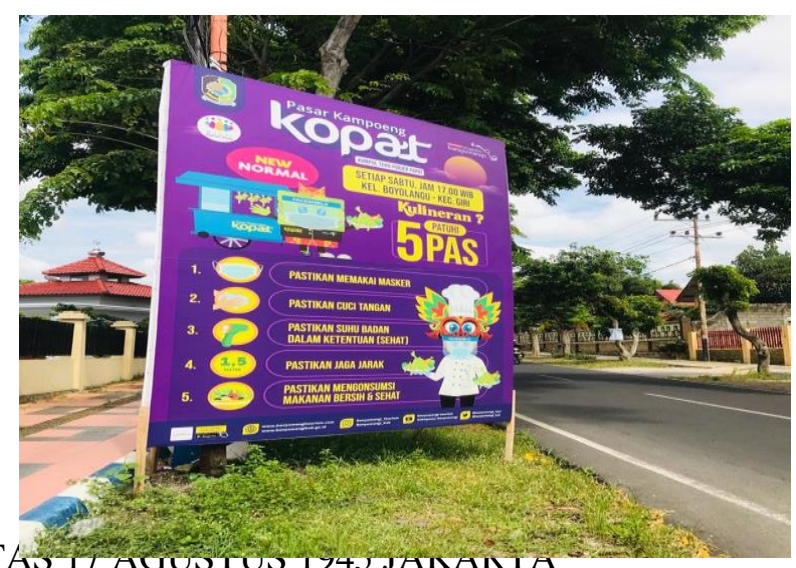




\section{F. Strategi event tradisi sebagai daya tarik kunjungan wisatawan dan peningkatan ekonomi masyarakat}

Strategi event tradisi sebagai daya tarik kunjungan wisatawan dan meningkatkan ekonomi masyarakat dapat diketahui dengan mengetahui bagaimana awal kemunculan event atau kegiatan yang diselenggarakan di desa, seperti yang disampaikan Ketua RT berikut ini :

“...Jadi kegiatan ini sebetulnya berawal dari tradisi tahunan yaitu Puter kayun dan kupat sewu yang diadakan bulan syawal hari ke tujuh, setelah itu praktis tidak ada kegiatan lagi. Kemudian setelah itu Pak Rido (sekertaris Dinas pariwisata) bertanya pada saya, bagaimana setelah ini?,apa tindak lanjutnya?, Jadi dari situlah kami berpikir untuk mengadakan event pasar kuliner kampoeng kopat setiap sabtu malam minggu supaya ada kelanjutannya..." (Ikhsan, tanggal 20 April 2020)

Dari kutipan wawancara tersebut diatas peneliti melihat bahwa peran Ketua RT selaku koordinator memiliki peran yang besar dalam menginisiasi diadakannya event ini, salah satu strateginya adalah membentuk tim yang terdiri dari lima orang. Mereka swadaya iuran Rp.200.000,- per orang. Lima orang tersebut antara lain :

1. Ketua RT : Bapak Ikhsan

2. Wakil Ketua RT : Khoirul Muhsin

3. Ketua RW : Samsul Hadi

4. Dinas Pariwisata : Erwin Prasetyo 


\section{Warga : Hadi}

Dengan dana yang sudah dikumpulkan secara swadaya tersebut kemudian dipergunakan untuk menyiapkan lokasi tempat diadakannya pasar kampoeng kopat, yaitu diawali dengan melakukan kerja bakti, menyiapkan tempat duduk, menutup saluran air atau got dengan bambu dan tanaman supaya terlihat indah. Baru kemudian mengkoordinir warga siapa saja yang mau mendaftar untuk dagang di event tersebut.

Dari informasi yang didapat peneliti di lapangan, diketahui bahwa awal mula pedagang yang mendaftar sebanyak 70 orang, terdiri dari warga asli boyolangu dan sisanya ada dari luar desa, seperti dari kelurahan penataban dan rogojampi, serta penjual keliling. Namun dari warga asli boyolangu keberatan ada yang protes karena ada pedagang dari luar, disamping itu ada pula pedagang yang tidak meneruskan berjualan karena alasan keluarga. Sehingga jumlah pedagang yang sekarang tinggal kurang lebih 30 pedagang.

Dalam melestarikan budaya atau tradisi Desa agar dikenal masyarakat luas, wisatawan lokal bahkan mancanegara Pemerintah keluarahan boyolangu tentunya sangat memberi dukungan terhadap keberhasilan dan kesuksesan event tersebut. Salah satunya dengan berkreasi dan membangun jaringan kerjasama untuk mendukung kegiatan atau event supaya di kenal masyarakat lebih luas. Staf kelurahan boyolangu menyatkan dalam wawancara berikut: 
“...bagaimana supaya event ini diketahui khalayak, kami sebagai aparatur kelurahan bekerjasama dengan Dinas Pariwisata. Apalagi warga kami, Mas Erwin itu orang dinas pariwisata, jadi lebih mempermudah kami untuk berkoordinasi memohon bantuan kerjasama seperti halnya sponsor sehingga bisa diketahui masyarakat luas..." (Ansori pada tanggal 13 April 2020).

Hal tersebut juga dibenarkan oleh staff Dinas Pariwisata, yang menyatakan sebagai berikut:

“...Dinas Pariwsata memberikan bantuan Promosi seperti baliho, media sosial, televisi dan mobile apps milik pemkab banyuwangi yang bisa diunduh di HP android melalui play store, bernama "Banyuwangi tourism" masuk pada item Njajan. Bagi pengguna iphone tidak bisa mengunduh aplikasi ini, jadi sementara ini hanya tersedia di HP android saja. Kemudian untuk media sosial tadi kita promosikan lewat instagram yang dikelola oleh dinas pariwisata dan ada juga akun khusus Instagram dengan nama: pasar_kampoeng_kopat, yang dikelola pemuda boyolangu supaya ada regenerasi dan dikelola secara mandiri. Selain itu untuk TV nasional, kami bekerjasama dengan Trans 7 dan Inews tv yaitu dengan cara memfasilitasi mereka untuk datang dan melakukan liputan di Banyuwangi, kita selipkan promosi pasar kuliner, salah satunya kampong koepat...."

(Erwin Prasetyo, tanggal 27 April 2020). 
Dari petikan wawancara diatas menunjukkan bahwa dalam hal ini Dinas pariwisata turut memberikan kontribusi yaitu dari segi promosi untuk event pasar kampong koepat supaya dikenal luas oleh masyarakat baik lokal, domestik, hingga turis mancanegara.

Disamping faktor pendorong berupa bantuan dari pemerintah pusat (kementerian), pemerintah kabupaten, dan instansi atau skpd terkait, tentunya perlu mengetahui faktor kendala dalam pelaksanaan event, supaya kedepan diperoleh solusi atas permasalahan yang ada. Kepala Kelurahan Boyolangu, dalam wawancara beliau mengatakan :

“...dalam kendala ya paling faktor cuaca seperti hujan, itu kan memang tidak bisa dihindari. Walaupun dari sisi pedagang sudah dipasang tenda supaya tidak terkena hujan, namun dari sisi pembeli tetap kehujanan karena kan tempatnya sendiri outdoor, sehingga kalau hujan ya bisa mengurangi jumlah pengunjung dan berdampak pada pendapatan warga yang berdagang di event pasar kampong koepat..." (Helmi Afandi, S.AP pada tanggal 27 April 2020). sedangkan jawaban dari Ikhsan selaku Ketua RT beliau mengatakan:

“...kendala sejauh ini, kalau ada acara dari pemda barengan Banyuwangi Festival (B-fest), otomatis pengunjung disini menurun, faktor cuaca seperti hujan. Karena disini kan tidak ada wisata, jadi kuliner ini yang kita genjot, dijadikan unggulan disini. Kemudian untuk restribusi kita tarik Rp.5000,- 
per pedagang untuk kas..."(Ikhsan, pada tanggal 27 April 2020).

Hal tersebut juga hampur sama dengan hasil wawancara dari masyarakat Desa yang mengatakan bahwa :

“...biasanya kalau hujan tiba-tiba tidak bisa kita prediksi (faktor alam), jadi agak sepi kalau pas hujan itu, orang kan malas keluar rumah. Kemudian proses pembuatan koepat yang memakan waktu agak lama, jadi apabila ada orang pesan itu apalagi dalam jumlah banyak minim $\mathrm{H}-4$, tidak bisa dadakan H-1 itu saja kita masih belum bisa, terlalu mepet waktunya. Disamping itu janur yang dipergunakan untuk pembungkus kopat itu agak sulit carinya, harus pesan di pengepul di Jambesari, kalau saya kebetulan punya sendiri pohonnya dirumah. Kalau beli 1 janur itu harganya Rp.300,-..”

(Haniah, pada tanggal 27 April 2020).

Hasil wawancara tersebut memperlihatkan bahwa kendala dalam menarik kunjungan ke pasar kampoeng kopat di kelurahan boyolangu sangat minim, karena semua terkoordinir dengan baik. Dalam pelaksanaanya peneliti juga melihat pedagang sangat antusias berjualan pada event ini. Hanya saja memang jualan pedagang yang belum support untuk dipesan pada aplikasi "Banyuwangi tourism" dikarenakan memang tidak tersedia setiap hari dan pembuatan bahan dasar kopat yang memakan waktu lama, serta janur sebagai pembungkus kopat yang harus pesan terlebih dahulu, 
dan kebanyakan warga memesan dari pengepul janur di Jambesari.

Berikut tabel faktor pendorong dan faktor penghambat dalam meningkatkan kunjungan wisatawan dan meningkatkan ekonomi masyarakat melalui event tradisi Kampong Kopat di Kelurahan Boyolangu, Kecamatan Giri Kabupaten Banyuwangi, dari hasil data dan pengamatan peneliti di lapangan sebagai berikut :

Tabel 1. Faktor Pendukung dan Faktor Penghambat

\begin{tabular}{|c|l|c|l|}
\hline No & \multicolumn{1}{|c|}{ PENDUKU } & NO & \multicolumn{1}{|c|}{ PENGHAMBA } \\
\hline D1 & $\begin{array}{l}\text { Bantuan Pemerintah Pusat } \\
\text { dan Pemerintah Kab. } \\
\text { Banyuwangi }\end{array}$ & H1 & $\begin{array}{l}\text { Biaya atau modal awal, karena } \\
\text { dilakukan secara swadaya } \\
\text { masyarakat }\end{array}$ \\
\hline D2 & $\begin{array}{l}\text { Bantuan Pemerintah } \\
\text { Kelurahan Boyolangu }\end{array}$ & H2 & $\begin{array}{l}\text { Kesejahteraan warga belum } \\
\text { menyeluruh, hanya sebagian } \\
\text { yang berdagang dalam event }\end{array}$ \\
\hline D3 & $\begin{array}{l}\text { Keikutsertaan pengurus } \\
\text { desa dan warga dalam } \\
\text { menyelenggarakan } \text { event } \\
\text { pasar kampoeng kopat }\end{array}$ & H3 & $\begin{array}{l}\text { Untuk pemesanan secara } \\
\text { online, belum mampu didukung } \\
\text { aplikasi mobile apps } \\
\text { "Banyuwangi Tourism" milik } \\
\text { pemkab banyuwangi, karena } \\
\text { lamanya pembuatan bahan } \\
\text { utama makanan yaitu "Kopat" }\end{array}$ \\
\hline D4 & $\begin{array}{l}\text { Perbaikan kesejahteraan } \\
\text { ekonomi masyarakat } \\
\text { boyolangu khususnya } \\
\text { pedagang yang terlibat } \\
\text { acara }\end{array}$ & H4 & $\begin{array}{l}\text { Kondisi pandemi Covid-19 saat } \\
\text { ini yang mengakibatkan } \text { event } \\
\text { tidak bisa terselenggara setiap } \\
\text { akhir pekan }\end{array}$ \\
\hline
\end{tabular}

Sumber : Data Primer Diolah Tahun 2020

Faktor pendorong dan faktor penghambat tersebut nantinya bisa dijadikan acuan kunci keberhasilan dalam peningkatkan daya tarik kunjungan wisatawan dan peningkatan 
ekonomi masyarakat melalui event tradisi "Pasar Kampoeng Kopat" di Kelurahan Boyolangu, Kecamatan Giri - Kabupaten Banyuwangi. Berikut adalah Faktor- faktor pendukungnya :

\section{Bantuan Pemerintah Pusat dan Pemerintah Kabupaten}

\section{Banyuwangi}

Dukungan pemerintah tentu sangat diperlukann untuk terselenggaranya acara tradisi budaya yang sesuai dengan tujuan pemerintah. Informasi yang didapatkan peneliti di lapangan bahwa dari Kementerian Perdagangan melalui pemerintah daerah memberikan bantuan sebanyak 25 (dua puluh lima) gerobak untuk pedagang berjualan, Kementerian Pariwisata berupa lampu hias jalan, dan senter, sedangkan dari pemerintah kabupaten banyuwangi melalui dinas pariwisata dan kebudayaan bantuannya berupa dukungan promosi baik baliho, sosial media, mobile apps, dan kerjasama dengan media televisi. Ada tiga tujuan utama diselenggarakannnya pasar kampoeng kopat, pertama adalah untuk mengangkat dan mengenalkan tradisi budaya lokal masyarakat. Melalui event ini harapannya masyarakat mau melestarikan dan mencintai budaya yang dimiliki. Tujuan kedua adalah untuk menarik kunjungan wisatawan ke boyolangu dan memperkenalkan kepada masyarakat luas potensi wisata yang dimiliki masyarakat boyolangu. Ketiga, untuk meningkatkan ekonomi masyarakat. Tentunya saat event Pasar kampoeng kopat diselenggarakan, maka perekonomian warga bisa terangkat. 
Dimana saat event dilaksanakan, pedagang yang berjualan dalam event tersebut memperoleh penghasilan, banyak didatangi pengunjung baik lokal hingga wisatawan mancanegara.

\section{Bantuan Pemerintah Kelurahan Boyolangu}

Dukungan pemerintah kelurahan boyolangu tentu sangat krusial dengan melihat berbagai perspektif, seperti: a. Pemberian ijin diselenggarakannya acara; peran pemerintah kelurahan boyolangu adalah dengan mendukung gagasan dari Ketua RT Krajan I selaku koordinator event pasar kampoeng kopat, b. Kerjasama Kelurahan dalam mengangkat tradisi desa menjadi potensi wisata; pihak kelurahan harus bisa berkreasi dan membangun kerjasama, misalnya bersama Dinas Pariwisata untuk memohon bantuan sponsor sehingga bisa dikenal dan dilihat masyarakat luas.

\section{Keikutsertaan pengurus desa dan warga dalam menyelenggarakan event pasar kampoeng kopat}

Keterlibatan aktif pengurus desa seperti Ketua RT, wakil Ketua RT, Ketua Rw beserta warga sangatlah penting guna menarik kunjungan wisatawan, mengenalkan tradisi desa, dan meningkatkan ekonomi masyarakat. Dari keterlibatan warga masyarakat lingkungan sekitar dalam event tersebut bisa sebagai tambahan penghasilan warga. Aparatur kelurahan juga memberikan kesempatan yang seluas-luasnya bagi masyarakat mau mendaftar ikut berdagang yang diserahkan kepada 
koordinator acara yaitu Ketua RT Krajan I. Hal ini sangat penting jika kita melihat peran pemerintah kelurahan mengacu pada Permendagri 28/2006, bahwa Kelurahan dibentuk untuk meningkatkan pelayanan kepada masyarakat, melaksanakan fungsi pemerintahan, dan pemberdayaan masyarakat dalam rangka mempercepat terwujudnya kesejahteraan masyarakat.

\section{Perbaikan kesejahteraan ekonomi masyarakat}

\section{boyolangu khususnya pedagang yang terlibat acara}

Dalam hal peningkatan ekonomi masyarakat, peneliti melihat cukup signifikan dari segi pendapatan, namun cukup untuk menambah penghasilan mereka, sebagian besar dari mereka bukan pedagang asli, namun karena merasa hasil yang diperoleh cukup signifikan, akhirnya mereka berlanjut sampai sekarang. Peneliti melihat bahwa selain melestarikan tradisi juga berpengaruh pada peningkatan perekonomian masyarakat dari warga yang mendaftar untuk ikut berjualan dalam acara tersebut, dan yang tak kalah pentingnya, nama Kelurahan Boyolangu bisa dikenal luas, dikunjungi oleh masyarakat. Baik lokal, domestik, dan wisatawan mancanegara yang berlibur di banyuwangi.

Selain kekuatan, tingkat kelemahan juga harus diminimalisir agar kekuatan tersebut dapat dimaksimalkan dan tidak mengganggu tujuan pelestarian tradisi guna meningkatkan kunjungan wisatawan dan mengembangkan perekonomian masyarakat Desa Boyolangu. Faktor penghambat harus 
didefinisikan sebagai kelemahan. Faktor penghambat ini nantinya akan ditetapkan sebagai kendala utama yang harus diminimalisir guna mencapai tujuan peningkatan kunjungan wisatawan dan pengembangan perekonomian masyarakat Desa Boyolangu. Faktor penghambatnya terdiri dari:

\section{Biaya atau modal awal minim, karena dilakukan secara swadaya masyarakat}

Pembiayaan atau modal merupakan tantangan pada saat awal akan diselenggarakannya pasar kampoeng kopat, karena menurut informasi dari Koordiator acara selaku Ketua RT Krajan I, awalnya dana bersumber dari swadaya masyarakat. Sehingga hal ini menjadi tantangan tersendiri, terlebih tidak semua warga yang ingin berjualan memiliki modal yang cukup.

\section{Kesejahteraan warga belum menyeluruh, hanya}

\section{sebagian yang berdagang dalam event}

Suatu kegiatan akan berjalan dengan baik apabila kegiatan tersebut mampu memberikan dampak yang luas bagi masyarakat sekitar. Saat ini, aktivitas pasar Kampoeng Kopat di Kelurahan Boyolangu, Kecamatan Giri, Kabupaten Banyuwangi belum mampu memberikan dampak yangmenyeluruh bagi masyarakat Boyolangu.Namun kesempatam diberikan seluas-luasnya kepada siapa saja warga yang berminat untuk mendaftar berjualan di event tersebut. Dari yang awalnya ada sekitar 40 (empat puluh) pedagang sampai 
saat ini tersisa kurang lebih 25 (dua puluh lima) sampai 30 (tiga puluh) pedagang.

\section{Pemesanan secara online, belum mampu didukung aplikasi mobile apps "Banyuwangi Tourism"}

Salah satu faktor yang bisa membantu terwujudnya kesuksesan pada suatu event atau kegiatan adalah dengan memanfaatkan teknologi yang memadai.

Kemajuan teknologi informasi mempermudah masyarakat untuk mengakses segala informasi dengan cepat dan mudah. Panitia Pasar Kampong Koepat dapat menggunakan berbagai fitur yang tersedia untuk memuat segala informasi tentang potensi wisata, konten kegiatan, lokasi kegiatan dan segala macam informasi yang dibutuhkan wisatawan, dan dalam hitungan detik segala informasi tentang Pasar Kampong Koepat bisa tersebar luas. Apalagi didukung dengan terobosan inovasi yang dilakukan Pemerintah Kabupaten Banyuwangi yang menghadirkan mobile apps "Banyuwangi Tourism". Pada aplikasi ini sebetulnya memiliki banyak item pilihan, seperti informasi: Ragam tempat wisata yang ada di Banyuwangi, Hotel, Paket wisata, rekomendasi restoran, agenda festival, pemesanan tiket pagelaran atraksi kesenian, serta Njajan untuk info kuliner dan pemesanan secara online,

Pada item Njajan ini sebetulnya hampir sama dengan GoFood milik Gojek, dengan tujuan agar pembeli bisa pesan 
makanan dan diantar. Hanya saja untuk kuliner kampoeng kopat ini terkendala makanan yang tidak tersedia setiap hari, jadi kemungkinan hanya bisa dipesan secara online pada saat event berlangsung yakni hari sabtu malam minggu. Alternatif lainnya menurut keterangan Ketua Rt selaku koordinator event adalah dengan menggunakan media sosial seperti Whatsapp. Sehingga Pembeli atau masyarakat diluar lingkungan Boyolangu bisa melakukan pesanan, dengan cara chat langsung ke penjual, kemudian diantar oleh penjual itu sendiri. Cara ini dianggap lebih efektif untuk pemesanan yang dilakukan secara online karena terhubung langsung ke penjual. Begitupun untuk masyarakat yang ingin memesan dalam jumlah banyak seperti untuk acara arisan, hajatan, dan sebagainya bisa dilakukan melalui whatsapp ini dengan ketentuan tidak bisa dilakukan secara mendadak, minimal H-4.

\section{Kondisi pandemi Covid-19 saat ini yang mengakibatkan event tidak bisa terselenggara setiap akhir pekan}

Di tengah pandemi covid-19, wisata kuliner menjadi salah satu sektor yang terkena dampaknya. Sehingga event praktis tidak dapat diselenggarakan sementara waktu. Baru saat masa tatanan normal baru, event baru diadakan sebanyak dua kali dan laris manis. Karena sudah lama libur, masyarakat yang sudah menunggu akhirnya ramai berbelanja. 
Mengenai penyelenggaraan event selama new normal tentunya sesuai dengan aturan protokol kesehatan baik penjual maupun pembeli. Dari informasi yang peneliti dapatkan, protokol yang diterapkan yaitu : penjual dan pembeli wajib memakai masker, panitia kegiatan menyiapkan sarana dan prasarana pendukung, seperti termogan (alat pengukur suhu), tempat cuci tangan, dan tenda isolasi (sebagai antisipasi barangkali ada pengunjung atau wisatawan yang suhunya tinggi). Menurut keterangan narasumber di lapangan, selama pandemi ini baru buka dua kali

\section{G. Dampak Event Pasar Kampong Koepat terhadap} peningkatan ekonomi masyarakat Kelurahan Boyolangu

Mengenai hal tersebut peneliti menanyakan kepada Kepala Lurah dan Staf bagaimana peningkatan pendapatan masyarakat dengan adanya event Pasar Kampong Koepat. Beliau menjawab :

“...supaya masyarakat ada pendapatan lain, disamping suaminya yang bekerja, kan gak nadong byaen jare wong banyuwangai nang wong lanang (tidak minta saja ke suami) munculah itu, masyarakat juga responsif. Perkiraan pendapatan bisa mencapai Rp.800.000,- sampai Rp.1.000.000,- ya sekitar itu..." (Helmi Afandi, S.AP pada tanggal 13 April 2020).

Sedangkan jawaban dari Ketua RT beliau mengatakan : “...dalam penambahan ekonomi itu relatif, ada yang dapat 300 rb, 700 rb, dan 800 rb, lihat kondisinya, jenis, serta banyaknya 
makanan yang dijual. jadi mereka itu malah kebanyakan mayoritas aslinya Ibu rumah tangga saja, yang aslinya pedagang pun ada, aslinya coba-coba trus keenakan lanjut, intinya kan untuk tambahan penghasilan saja. Jadi yang murni dagang dibuat sambian, karena kan cuma seminggu sekali eventnya. Untuk siapa saja masyarakat yang mau bergabung jualan, siapa saja yang berminat silahkan mendaftar..." (Ikhsan, pada tanggal 13 April 2020)

Hal tersebut dibenarkan oleh beberapa pedagang seperti Haniah yang merupakan istri Ketua RT.

Beliau mengatakan bahwa :

“...saya sendiri berjualan kupat kare, ayam opor, dan minuman, pendapatan dalam sehari atau sekali event itu Rp.450.000,- pendapatan kotornya. Ya bagi saya yang asli Ibu rumah tangga, sangat lumayan untuk tambahan penghasilan, apalagi suami saya ketua RT. Jadi kami sekaligus memberi contoh agar warga antusias mau jualan di pasar kampoeng kopat ini..." (Haniah, pada tanggal 13 April 2020)

Dari hasil wawancara di atas, dalam hal penghasilan, peneliti melihat bahwa cukup berdampak bagi peningkatan perekonomian warga yang berjualan pada saat acara terselenggara. Peneliti melihat bahwa Ketua RT sebagai koordinator kegiatan yang memprakarsai acara bersama dengan dukungan aparat lingkungan lainnya, para kepala desa dan warga sangat antusias dan juga berperan serta baik dalam 
melestarikan tradisi desa, sehingga makanan tradisional warga Desa Boyolangu bisa dikenal luas dan acara bisa dikunjungi. Warga lokal, wisatawan domestik, dan warga negara asing yang sedang berlibur di Banyuwangi, bisa diarahkan oleh travel agent dan support dari dinas pariwisata untuk datang ke Boyolangu.

\section{KESIMPULAN DAN SARAN}

Berdasarkan temuan hasil penelitian yang telah dikemukakan pada bab sebelumnya, peneliti menarik kesimpulan bahwa event tradisi sebagai daya tarik kunjungan wisatawan: Studi kasus Pasar kampong koepat Kelurahan Boyolangu, Kecamatan Giri, Kabupaten Banyuwangi dapat terwujud. Boyolangu sendiri sebetulnya memiliki banyak potensi kuliner, potensi adat, pariwisata, kebijakan potensial, dan potensi koperasi perempuan. Berbagai potensi tersebut dimanfaatkan oleh Kelurahan Boyolangu melalui proses integrasi bersama antara pemerintah dan masyarakat melalui nilai dan simbol yang digunakan untuk memberdayakan masyarakat Boyolangu dengan dihasilkannya Inovasi Pasar Jajanan Kampoeng Kopat di Boyolangu.

Mekanisme proses dan metode yang digunakan masyarakat dalam berintegrasi dari kegiatan ini dilaksanakan oleh Ketua RT, wakil Ketua RT, Ketua RW Boyolangu, tokoh desa, kelurahan boyolangu dan partisipasi masyarakat untuk menggali potensi menghadirkan destinasi wisata baru yaitu, Kampoeng Kopat. 
Pasar wisata kuliner sendiri terus dikembangkan oleh Kabupaten Banyuwangi. Ditengah kelesuan ekonomi, tentu diperlukan inovasi untuk menggerakkan berbagai sektor. Pasar kuliner ini adalah salah satu cara untuk mendongkrak ekonomi lokal di masing-masing desa.

Mengenai faktor pendorong dan penghambat nantinya bisa dijadikan acuan kunci keberhasilan dalam peningkatkan daya tarik kunjungan wisatawan dan peningkatan ekonomi masyarakat melalui event tradisi "Pasar Kampoeng Kopat" di Kelurahan Boyolangu, Kecamatan Giri - Kabupaten Banyuwangi. Faktor pendukung antara lain : 1).Bantuan pemerintah pusat dan pemerintah kabupaten banyuwangi; 2). Bantuan Pemerintah Kelurahan Boyolangu; 3). Keikutsertaan pengurus desa dan warga dalam menyelenggarakan event pasar kampoeng kopat; 4). Perbaikan kesejahteraan ekonomi masyarakat boyolangu khususnya pedagang yang terlibat acara. Sedangkan faktor penghambat atau kendala antara lain: 1). Minimnya biaya atau modal, karena dilakukan secara swadaya masyarakat; 2). Perbaikan kesejahteraan masyarakat yang belum menyeluruh, hanya warga yang terlibat event; 3). Pemesanan secara online, belum mampu didukung aplikasi mobile apps "Banyuwangi Tourism" milik pemkab banyuwangi, karena lamanya pembuatan bahan utama makanan yaitu "Kopat"; 4). Kondisi pandemi Covid19 saat ini yang mengakibatkan event tidak bisa terselenggara setiap akhir pekan. 


\section{DAFTAR PUSTAKA}

Fahrudin, Adi. 2012. Pemberdayaan, Partisipasi dan Penguatan

Kapasitas Masyarakat.

Bandung: Humaniora.

Getz, Donald. (1991), Festivals, Special Events, and Tourism,

New York: Van Nostrand Reinhold

Najiati, Sri, dkk. 2005. Pemberdayaan Masyarakat di Lahan

Gambut. Bogor: Wetlands

International.

Hikmat, Harry. 2006. Strategi Pemberdayaan Masyarakat.

Bandung: Humaniora.

https://www.kajianpustaka.com/2017/11/tujuan-prinsip-

dan-tahapanpemberdayaan-masyarakat.html

Mardikanto, Totok. 2014. CSR (Corporate Social

Responsibility)(Tanggungjawab Sosial

Korporasi). Bandung: Alfabeta.

Soekanto, Soerjono. 1987. Sosial Suatu Pengantar. Jakarta:

Rajawali press.

Sugiyono. 2009. Metode Penelitian Kuantitatif Kualitatif dan

R\&D. Bandung: Alfabeta.

Suharto, Edi. 2005. Membangun masyarakat memberdayakan rakyat. Bandung: Refika

Aditama.

https://www.kabarbanyuwangi.info/destinasi-digital-pasar-

kampoeng-kopat-siapmeluncur-di-banyuwangi.html 
PROMEDIA (PUBLIC RELATION DAN MEDIA KOMUNIKASI) ISSN2460-9633

Volume Ke-7 No. 1, 2021, Permatasari,dkk, Event Tradisi, hal 157-hal 191.

https://news.detik.com/berita-jawa-timur www.banyuwangitourism.com" 